\title{
PENGARUH WAKTU FERMENTASI TERHADAP PERSENTASE PENYISIHAN PADATAN TERSUSPENSI TOTAL (TSS) CAMPURAN LIMBAH CAIR INDUSTRI TAPIOKA DENGAN AIR
}

\author{
Wan Rizki Ansari, Umayi Belladiana, Setiaty Pandia \\ Departemen Teknik Kimia, Fakultas Teknik, Universitas Sumatera Utara, \\ Jl. Almamater Kampus USU Medan 20155, Indonesia \\ Email : wanrizkiansari@yahoo.com
}

\begin{abstract}
Abstrak
Limbah cair industri tapioka merupakan limbah hasil proses pencucian bahan baku, penyaringan bubur singkong (ekstraksi) dan endapan pati yang masih mengandung senyawa organik penting terutama pati dan senyawa lain sehingga dapat dijadikan sebagai bahan baku pembuatan gas bio. Penelitian ini bertujuan untuk mengetahui pengaruh waktu fermentasi terhadap persetase penyisihan padatan tersuspensi total (TSS) dengan menggunakan digester anaerobik sistem batch. Penelitian dilakukan dengan mencampurkan limbah cair industri tapioka dengan air dengan perbandingan 100:0; $85: 15 ; 65: 35 ; 50: 50 ; 35: 65$; dan 15:85 (v/v ) dengan starter kotoran sapi di dalam digester anaerobik sistem batch dengan $\mathrm{pH}$ campuran diatur netral. Parameter uji yang dilakukan adalah kandungan padatan tersuspensi total. Persentase penyisihan padatan tersuspensi total optimal tercapai pada perbandingan volume limbah cair dengan air sebesar 100:0 (v/v) dengan nilai optimal sebesar $89,851 \%$ pada hari ke- 21 .
\end{abstract}

Kata kunci: limbah cair industri tapioka, anaerob digester, TSS

\begin{abstract}
The waste water of tapioca is the waste produced from the washing process raw materials, screening cassava porridge (extraction) and starch sediment containing organic compounds which are still important, especially starch and other compounds that can be used as raw material for the manufacture of bio gas. This study aimed to determine the effect of fermentation time on the elimination percentage of Total Suspended Solid (TSS) using batch anaerobic digester system. Research was carried out by mixing the liquid waste of tapioca industry with water in the ratio 100:0, $85: 15 ; 65: 35 ; 50: 50 ; 35: 65$, and 15:85 ( $v / v)$ with starter in an anaerobic digester system batch in which neutral $\mathrm{pH}$ of the mixture was set. Parameter observed was the content of Total Suspended Solid. Percentage of elimination of Total Suspended Solid was reached at the rasio of liquid waste to water 100:0 $(\mathrm{v} / \mathrm{v})$ with the optimal value of $89.851 \%$ on the $21^{\text {th }}$ day.
\end{abstract}

Keywords: tapioca industry liquid waste, anaerobic digester, TSS

\section{Pendahuluan}

Menipisnya bahan bakar pembangkit yang tersedia membuat PLN harus mengurangi daya listrik yang disalurkan sehingga dilakukan pemadaman bergilir. Bahan bakar listrik yang digunakan saat ini berasal dari bahan bakar fosil yang tidak dapat diperbaharui sehingga suatu saat pasti akan mengalami kehabisan stock bahan bakar [15].

Solusi kelangkaan energi (bahan bakar) salah satunya adalah menerapkan teknologi biogas dengan menggunakan bahan baku tanaman holtikultura dan palawija. Karena limbah hasil ekstraksi tanaman tersebut mengandung zat pati yang dapat dengan mudah terfermentasi oleh bakteri [2].

Metana yang dihasilkan tersebut adalah gas yang dapat terbakar sehingga dapat dijadikan sumber energi alternatif terbarukan dengan cara menangkap gas tersebut melalui bioreaktor anaerobik [14]. Pada dasarnya limbah dapat mengalami perubahan secara biologis sehingga dapat dikonversikan ke produk lain [16].

Berdasarkan hasil pengukuran emisi gas di kolam anaerobik industri tapioka menunjukkan bahwa setiap satu ton ubi kayu dapat menghasilkan $24,4 \mathrm{~m}^{2}$ biogas atau $14,6-15,8 \mathrm{~m}^{2}$ metana per ton ubi kayu yang diolah [1].

Diharapkan dengan diketahui kondisi fermentasi yang optimal dalam menghasilkan biogas, energi baru terbarukan yang dihasilkan dapat mensuplai kebutuhan energi pada industri tersebut sehingga dapat mengurangi dampak meningkatkan daya saing industri, dan sekaligus dapat mengurangi dampak pemanasan global yang memicu perubahan iklim global [14]. Tujuan dari penelitian ini adalah mengetahui pengaruh waktu fermentasi terhadap persetase penyisihan TSS dengan menggunakan digester anaerobik sistem batch dihasilkan dari limbah cair singkong dari industri tapioka yang dikombinasikan dengan air. 


\section{Teori}

Ubi kayu (Mannihot esculenta) berbatang berkayu dan beruas - ruas yang tingginya mencapai 3 meter atau lebih [11]. Bagian tengah dari ubi kayu bergabus dan termasuk tumbuhan yang tinggi. Ubi kayu bisa mencapai ketinggian 14 meter. Pemeliharaannya mudah dan produktif [17]. Kandungan kimia yang terdapat pada ubi kayu adalah kalori, protein, lemak, karbohidrat, akalsium, fosfor, besi, vitamin B1, vitamin $\mathrm{C} 1$, dan air [9].

Limbah industri tapioka dapat dibedakan menjadi dua yaitu limbah padat dan limbah cair [4]. Menurut Greenfield [8], limbah pabrik tapioka banyak mengandung bahan organik seperti pati, serat, protein, gula dan sebagainya. Komponen limbah ini merupakan bagian sisa pati yang tidak terekstrak serta komponen non pati yang terlarut dalam air. Sehingga tepung tapioka adalah komponen pati yang hampir murni. Namun industri tepung tapioka pada saat ini sering menimbulkan masalah lingkungan. Limbah padat seperti kulit singkong dapat dimanfaatkan untuk pakan ternak dan pupuk, sedangkan onggok (ampas) dapat digunakan sebagai sebagai bahan baku pada industri pembuatan saus, campuran kerupuk, obat nyamuk bakar dan pakan ternak. Limbah cair dapat dimanfaatkan untuk pengairan sawah dan ladang, selain itu limbah cair pengolahan tapioka dapat diolah menjadi minuman nata de cassava dan pembuatan gas bio [17].

Gas bio adalah gas yang dihasilkan oleh aktifitas anaerobik atau fermentasi dari bahan bahan organik termasuk diantaranya kotoran manusia dan hewan, limbah domestik, sampah biodegradable atau setiap limbah organik yang biodegradable dalam kondisi anaerobik. Kandungan utama dalam biogas adalah metana dan karbon dioksida [6]. Biogas hanya dapat terbakar apabila kandungan metana di dalamnya mencapai $45 \%$ atau lebih [7].

Bahan organik $\rightarrow \mathrm{CH}_{4}+\mathrm{CO}_{2}+\mathrm{CO}+\mathrm{N}_{2}+\mathrm{H}_{2}+\mathrm{H}_{2} \mathrm{~S}+\mathrm{O}_{2}$ (mikroorganisme/anaerobik)

Pada proses anaerob, bahan organik didegradasikan menjadi metana dan karbon dioksida melalui tahap-tahap berlainan yang merupakan serangkaian kegiatan metabolik dari kelompok-kelompok mikroorganisme yang berbeda. Adapun tahap-tahap ini dapat dibedakan menjadi 4 tahap utama yaitu: Hidrolisis dan Asidifikasi, Asidogenesis. Asetogenesis dan Metanogenesis [3]. Faktor-faktor lingkungan utama yang mempengaruhi proses metanogenesis adalah komposisi air limbah, suhu, $\mathrm{pH}$, waktu tinggal hidrolik dan konsentrasi asam - asam volatil [18].

\section{Metodologi Penelitian \\ Bahan dan Alat}

Bahan yang digunakan adalah limbah cair industri tapioka dan air sebagai bahan baku, sebagai bahan pembantu digunakan molase dan mikroorganisme yang berasal dari kotoran sapi yang dicampur dengan air dengan perbandingan 1:1 yaitu $25 \%$ dari volume reaktor terisi $(400 \mathrm{~L})$. Alat utama yang digunakan adalah digester anaerobik untuk proses fermentasi.

\section{Prosedur Penelitian}

Limbah cair industri tapioka dan air dimasukkan ke dalam tangki digester yang memiliki volume $400 \mathrm{~L}$ dengan variasi komposisi limbah cair : air adalah 100:0; 85:15; 65:35; 50:50; 35:65 dan 15:85 (dalam \% volume). Kemudian ditambahkan starter (kotoran sapi) dan difermentasikan. Tangki digester dihubungkan dengan bladder (tempat penampungan gas) sehingga gas yang terbentuk akan masuk ke bladder. Volume gas diukur setiap tiga hari. Pada tahap ini, percobaan dilakukan pada digester anaerobik sistem batch dengan $\mathrm{pH}$ dijaga konstan antara $6-7$ dengan menggunakan larutan penyangga (buffer), yaitu larutan kapur $\left(\mathrm{Ca}(\mathrm{OH})_{2}\right)$ atau kapur $\left(\mathrm{CaCO}_{3}\right)$ pada temperatur lingkungan. Bakteri anaerobik yang telah diaklimatisasi dicampur dengan limbah dengan perbandingan jumlah limbah : kotoran sapi adalah 75 : 25 (dari perancang digester), lalu diamati parameterparameter percobaan yaitu TSS. Dalam penelitian ini, pengamatan dilakukan setiap 3 hari.

\section{Penentuan Konsentrasi Padatan Tersuspensi Total}

Kertas saring dipanaskan pada suhu $105^{\circ} \mathrm{C}$ selama 1 jam lalu dinginkan dalam desikator dan timbang hingga beratnya konstan (B gram). Diambil $10 \mathrm{ml}$ sampel lalu saring dan residu pada kertas saring dipanaskan pada $105^{\circ} \mathrm{C}$ selama 1 jam lalu masukkan dalam desikator dan timbang hingga berat konstan (A gram).

Kadar zat TSS dapat dihitung dengan persamaan 1 .

$\operatorname{TSS}\left(\frac{\mathrm{mg}}{\mathrm{L}}\right)=\frac{(\mathrm{A}-\mathrm{B}) \times 1000}{\mathrm{C}}$

Dimana:

$\mathrm{A}=$ Berat filter dan residu sesudah pemanasan $105{ }^{\circ} \mathrm{C}(\mathrm{mg})$

$\mathrm{B}=$ Berat filter kering sesudah pemanasan $105{ }^{\circ} \mathrm{C}$ (mg)

$\mathrm{C}=$ Volume sampel (ml) 


\section{Hasil dan Pembahasan}

TSS merupakan salah satu parameter yang penting dalam pengolahan limbah industri tapioka. Oleh karena itu, dari gambar dibawah ini dapat dilihat perubahan nilai TSS selama proses fermentasi di dalam digester anaerobik.

Pengaruh waktu fermentasi terhadap persentase penyisihan TSS dapat dilihat pada gambar 1 .

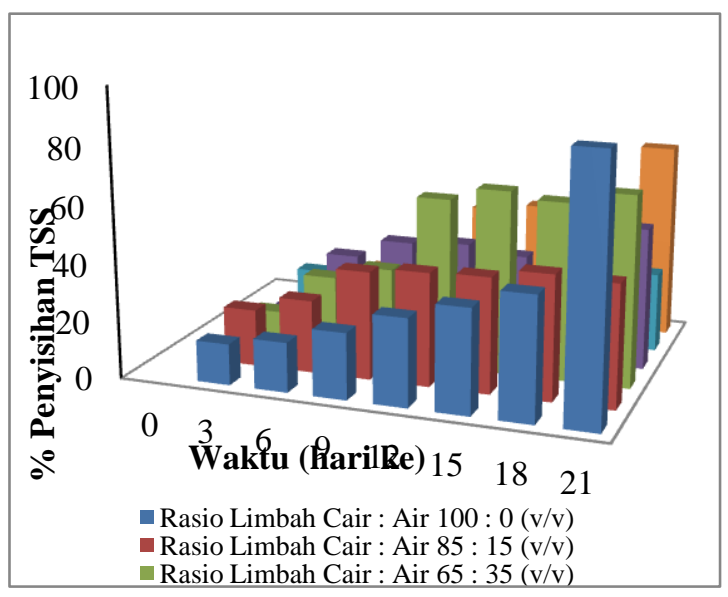

\section{Gambar 1. Pengaruh Waktu Fermentasi Terhadap Persentase Penyisihan Total Suspended Solid}

Dari gambar 1 dapat dilihat bahwa waktu fermentasi berpengaruh terhadap \% penyisihan TSS secara fluktuatif. Pada perbandingan volume rasio limbah cair dan air 100:0 dengan persentase penyisihan TSS terbesar yaitu $89,85 \%$ pada hari ke-21, untuk perbandingan volume rasio limbah cair dan air 85:15 dengan persentase penyisihan TSS terbesar yaitu 43,36\% pada hari ke-18. Pada perbandingan volume rasio limbah cair dan air 65:35 dengan persentase penyisihan TSS terbesar yaitu $66,27 \%$ pada hari ke-21, untuk perbandingan volume rasio limbah cair dan air 50:50 dengan persentase penyisihan TSS terbesar yaitu $49,54 \%$ pada hari ke-21. Pada perbandingan volume rasio limbah cair dan air 35:65 dengan persentase penyisihan TSS terbesar yaitu $48,88 \%$ pada hari ke-18, untuk perbandingan volume rasio limbah cair dan air 15:85 dengan persentase penyisihan TSS terbesar yaitu $68,98 \%$ pada hari ke- 21 .

TSS atau total zat padat tersuspensi diklasifikasikan menjadi zat padat dan melayang yang bersifat organis dan zat padat terendap yang dapat bersifat organis dan anorganis. Zat padat terendap adalah zat padat dalam suspensi yang dalam keadaan tenang dapat mengendap setelah waktu tertentu karena pengaruh gaya beratnya. Penentuan zat padat terendap tersebut dapat melalui volumenya yang disebut dengan analisis volume lumpur (sludge volume) dan dapat melalui bobotnya yang disebut dengan analisis lumpur kasar atau umumnya disebut zat padat terendap (settleable solids)[13].

Adapun hasil yang berfluktuasi dapat disebabkan oleh beberapa faktor lingkungan proses juga harus direkayasa dan dikendalikan. Faktorfaktor lingkungan utama yang mempengaruhi proses metanogenesis adalah komposisi air limbah, suhu, $\mathrm{pH}$, waktu tinggal hidrolik dan konsentrasi asam-asam volatil. Produksi gas metana selama proses degradasi bahan organik dipengaruhi oleh jumlah dan komposisi air limbah yang digunakan sebagai substrat [18].

Total Solid yang dimiliki oleh limbah cair industri tapioka menurut SK MENLH KEP51/MENLH/I0/1995 belum layak apabila langsung dilepaskan ke perairan lepas, yaitu lebih besar dari pada $150 \mathrm{mg} \mathrm{L}^{-1}$. Pada penelitian ini, Total Solid yang paling sedikit dimiliki oleh perbandingan rasio limbah cair industri tapioka dan air 100:0 (v/v) adalah $370 \mathrm{mg} \mathrm{L}^{-1}$ pada hari ke-21. Proses fermentasi selama 21 hari telah mendegradasi TSS yang terdapat dalam limbah. Perombakan TSS oleh mikroorganisme telah mengakibatkan penurunan nilai TS. Proses fermentasi selama 21 hari menghasilkan TSS sebesar $370 \mathrm{mg} \mathrm{L}^{-1}$ ternyata belum mampu menurunkan nilai TSS hingga memenuhi syarat, meskipun persentasi penurunan pada perlakuan TSS merupakan persentase terbesar dibandingkan perlakuan lainnya.

Alternatif lain seperti yang dilakukan Belladiana (2013) dengan menambahkan adsorben dari kulit singkong sehingga persentase penyisihan TSS akan semakin besar sehingga nilai TSS limbah cair turun dari $976 \mathrm{mg} / \mathrm{L}$ menjadi 39,26 $\mathrm{mg} / \mathrm{L}$ yang tercapai pada kondisi perbandingan volume limbah cair industri tapioka dan air 100:0 (kondisi terbaik).

\section{Kesimpulan}

Pengaruh waktu fermentasi terhadap persentase penyisihan TSS adalah semakin lama waktu fermentasi maka persentase penyisihan akan semakin besar. Dalam hal ini, persentase penyisihan TSS terbesar pada hari ke-21 diperoleh pada perbandingan volume limbah cair industri tapioka dan air 100:0 (v/v) yaitu 89,851\%.

\section{Daftar Pustaka}

[1] Adelekan, B.A dan Bamgboye, A.I, Comparison of Biogas Productivity of Cassava Peels Mixed in Selected Ratios with Major Livestock Waste Types, African Journal of Agricultural Research, Vol 4, pp. 571-577, Juli 2009.

[2] Agung, Cara Cepat Membuat Biogas Dari Kotoran Hewan dan Sampah Dirumah, http://rumahenergi.com/, Diakses pada tanggal 16 Mei 2012, 2012. 
[3] Agustina, Fransiska, Aplikasi Parameter Produk Biogas dari Limbah Cair Industri Tapioka dalam Bioreaktor Anaerobik 2 Tahap, Tesis, Teknik Kimia, Universitas Diponegoro, Semarang, 2011.

[4] Bangun, J. F. Sihombing, Penggunaan Media Filtran dalam Upaya Mengurangi Beban Cemaran Limbah Cair Industri Kecil Tapioka, Skripsi, Departemen Teknologi Industri Pertanian, Fakultas Teknologi Pertanian Institut Pertanian, 2007.

[5] Belladiana, Umayi, Pengaruh Komposisi Campuran Limbah Cair Industri Tapioka dengan Air terhadap Gas Bio yang dihasilkan, Laporan Hasil Penelitian, Departemen Teknik Kimia, Fakultas Teknik, Universitas Sumatera Utara, 2013, hal. 43 - 44.

[6] Fitri, Produksi Angkak oleh Monascus Purpureus dalam Medium Limbah Tapioka, Ampas Tapioka dan Ampas Tahu, Buletin, Teknik dan Industri Pangan, Vol. V, no. 3, 2009.

[7] Garcelon dan Clark, Komposisi Biogas, http://www.Gasbio.com/, Diakses pada tanggal 29 April 2012, 2007.

[8] Greenfield, R. E, Industrial Waste Water Control. A Text Book and Reference Book, Departement of Civil Engineering Illionis, Institute of Technology Chicago, Illionis, 1971.

[9] IPTEK, Tanaman Obat Indonesia, Sentra Informasi IPTEK, BPPT, 2010.

[10] Lampiran B, VIII KEP-51/ MNLH/ 10/, 1995.

[11] Rukmana, Rahmat, Ubi Kayu Budi Daya dan Pascapanen, (Yogyakarta: Kanisius, 1997), hal. 71

[12] Sangyoka. S, Reungsang. A dan Monamart. S, Repeated-batch Fermentative for Biohydrogen Production from Cassava Starch Manufacturing Wastewater, Department of Biotechnology and Fermentation Research Center for value Added Agricultural Products, Faculty of Technology, Khon KaenUniversity, A. Thailand, Pakistan Journal Of Biological Sciences 10 (1):1782-1789, 2007.

[13] Suroso, Erdi, Model Proses Produksi Industri Tapioka Ramah Lingkungan Berbasis Produksi Bersih, Tesis, Institut Pertanian Bogor, 2011.

[14] Surya, H, Produksi Biogas Pengolahan Limbah Cair Industri Tapioka, http://tapiokapati.com/, Diakses pada tanggal 12 Mei 2012, 2009.

[15] Sutrisno, Aplikasi Reaktor Biogas Sistem Colar sebagai Alternatif Sumber Energi sebagai Upaya Pemanfaatan Limbah Cair
Industri Tapioka, Tesis, Institut Pertanian Bogor, 2010.

[16] Ubalua, Cassava Wastes: Treatment Options and Value Addition Alternatives, Cassava Research Programme, African Journal of Biotechnology Vol. 6 (18), pp. 2065-2053, 19 September 2007.

[17] Widianta, Ardhiles dan Deva, Widi Prima, Ubi Kayu (Manihhot esculenta) Sebagai Bahan Alternatif Pengganti Bensin (Bioethanol) yang Ramah Lingkungan, SMA Negeri 6 Bengkulu, Diakses pada tanggal 3 Mei 2012.

[18] Wintolo, Marhento dan Rochman Isdiyanto, Prospek Pemanfaatan Biogas dari Pengolahan Air Limbah Industri Tapioka, Skripsi, Pusat Penelitian dan Pengembangan Teknologi Ketengalistrikan, Energi Baru, Terbarukan dan Konservasi Energi, 12:103-112, 2011. 